${ }^{14}$ Oliveira JF, Braga ACS, Oliveira MBN, Ávila AS, Caldeira-deAraújo A, Cardoso VN, Bezerra RJAC, Bernardo-Filho M. Assessment of the effect of Maytenus ilicifolia (espinheira santa) extract on the labeling of red blood cells and plasma proteins with Technetium-99m. Journal of Ethnopharmacology 2000; 72: 179-84

${ }^{15}$ Oliveira JF, Braga ACS, Ávila AS, Fonseca LMB, Gutfilen B, Bernardo-Filho M. Effect of Thuya occidentalis on the labeling of red blood cells and plasma proteins with Technetium-99m. Yale Journal of Biology and Medicine. 1996; 69: 489-94

${ }^{16}$ Braga ACS, Oliveira MBN, Feliciano GD, Reiniger IW, Oliveira JF, Silva CR Bernardo-Filho M. The effect of drugs on the labeling of blood elements with Technetium $-99 \mathrm{~m}$. Current Pharmaceutical Design 2000; 6: 1179-91

${ }^{17}$ Reiniger IW, Oliveira JF, Caldeira-de-Araújo A, Bernardo-Filho M. Effect of Peumus boldus on the labeling of red blood cells and plasma proteins with Technetium-99m. Applied Radiation and Isotopes 1999; 51: 145-9

\title{
Identificação de marcadores croma- tográficos de Zollernia ilicifolia e Sorocea bonplandii para o controle de qualidade de espinheira-santa
}

\author{
Michele Debiasi Alberton ${ }^{1}$;Ester Santos de Souza ${ }^{2}$; Daniel de \\ Barcellos Falkenberg ${ }^{3}$; Miriam de Barcellos Falkenberg ${ }^{4 *}$ \\ ${ }^{1}$ Programa de Pós-Graduação em Farmácia \\ ${ }^{2}$ Curso de Graduação em Farmácia e Bioquímica \\ ${ }^{3}$ Departamento de Botânica \\ ${ }^{4}$ Departamento de Ciências Farmacêuticas \\ Centro de Ciências da Saúde, Universidade Federal de Santa \\ Catarina, Campus Universitário Trindade, 88040-900, \\ Florianópolis, SC, Brasil \\ miriam@cos.ufsc.br
}

\section{Resumo}

As análises cromatográficas comparativas entre Maytenus ilicifolia Martius ex Reissek (Celastraceae), utilizada na medicina popular para o tratamento de problemas gástricos e Zollernia ilicifolia (Brongniart) Vogel (Fabaceae) e Sorocea bonplandii (Baillon) Burger, Lanjouw \& Boer (Moraceae) revelaram a presença de uma substância marcadora para $Z$. ilicifolia e três para $S$. bonplandii, que podem ser usadas no controle de qualidade por CCD de amostras vegetais e fitoterápicos à base de espinheira-santa.

Maytenus ilicifolia Martius ex Reissek (Celastraceae), conhecida popularmente como "espinheira-santa", é uma espécie usada na medicina popular para o tratamento de problemas digestivos ${ }^{1}$, e é bem conhecida tanto do ponto de vista químico como farmacológico ${ }^{2,3}$. O extrato aquoso desta espécie apresentou efeitos antiúlcera em pacientes portadores de dispepsia alta ou úlcera péptica ${ }^{3}$. Seu extrato clorofórmico apresentou também atividade analgésica e antiinflamatória em camundongos ${ }^{4}$.

Devido à similaridade morfológica, Zollernia ilicifolia (Brongniart) Vogel (Fabaceae) e Sorocea bonplandii (Baillon) Burger, Lanjouw \& W. Boer (Moraceae), que também têm as margens espinhosas, são facilmente confundidas com a espinheira-santa ${ }^{5,6}$. Para a espécie Maytenus ilicifolia, considerada como espinheira-santa "verdadeira", e Maytenus aquifolium também considerada verdadeira por muitos pesquisadores, já existem marcadores químicos como friedelina e friedelanol, que podem ser utilizados no controle de qualidade ${ }^{7}$. Para Z. ilicifolia e Sorocea bonplandii, entretanto, não haviam sido descritas na literatura substâncias que servissem como marcadores destas espécies na análise por cromatografia em camada delgada, uma metodologia rápida e reprodutível ${ }^{8}$. Em decorrência disto, o objetivo do trabalho foi comparar extratos 
de Maytenus ilicifolia, Zollernia ilicifolia e Sorocea bonplandii com vistas à identificação de substâncias que possam servir como marcadores químicos destas duas últimas, uma vez que elas se constituem em potenciais adulterantes de espinheirasanta.

$\mathrm{Na}$ análise em placas de gel de sílica $60 \mathrm{~F}_{254}$ utilizando éter de petróleo/ acetato de etila (85:15), foi detectada, em todos os extratos de Z. ilicifolia uma substância característica em Rf 0,57, sem fluorescência a $365 \mathrm{~nm}$ nem extinção de fluorescência a $254 \mathrm{~nm}$, apresentando coloração azul-clara após revelação com timol-sulfúrico e coloração violácea após a revelação com anisaldeído-sulfúrico (figura 1).

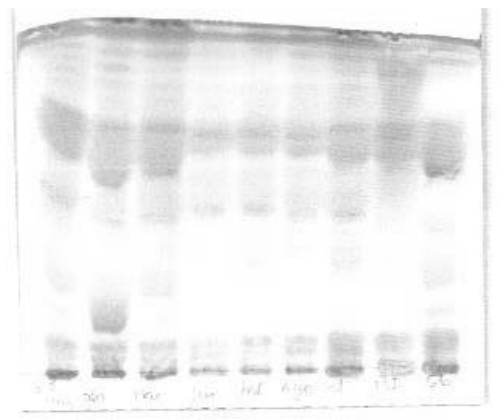

Figura 1. Análise cromatográfica das coletas de Zollernia ilicifolia. 1 . Coleta março/2000; 2. Abril/2000; 3. Maio/2000; 4. Junho/2000; 5.Julho/2000; 6. Agosto/2000; 7. Setembro/2000; 8. Maytenus ilicifolia; 9. Sorocea bonplandii. As manchas em destaque são a substância marcadora de Zollernia ilicifolia (Rf $0,57)$.

Utilizando como fase móvel éter de petróleo/ diclorometano (3:1) foram detectadas três substâncias características em todos os extratos de $S$. bonplandii, em Rf 0,40, 0,46 e 0,53, desprovidas de fluorescência a $365 \mathrm{~nm}$ e extinção de fluorescência a $254 \mathrm{~nm}$, apresentando cor rósea após a revelação com timol-sulfúrico e violácea, após a revelação com anisaldeído-sulfúrico (figura 2).

O monitoramento sazonal destas espécies continua sendo realizado, para confirmar a presença destes marcadores nas plantas ao longo do ano. Os resultados obtidos sugerem que as substâncias ora propostas como marcadores químicos para as espécies Zollernia ilicifolia e Sorocea bonplandii constituem-se em substâncias potencialmente de grande valia no controle de qualidade de preparações à base de espinheirasanta.

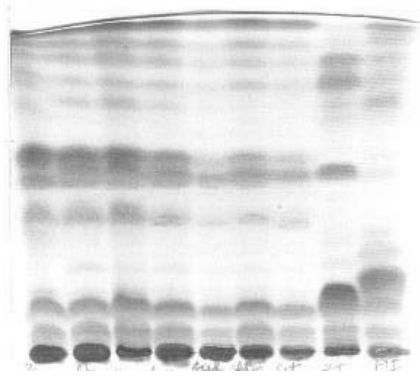

Figura 2. Análise cromatográfica das coletas de Sorocea bonplandii. 1. Coleta março/2000; 2. Abril/2000; 3. Maio/2000;
4. Junho/2000; 5.Julho/2000; 6. Agosto/2000; 7. Setembro/2000; 8. Zollernia ilicifolia; 9. Maytenus ilicifolia. Em destaque em Sorocea bonplandii : substâncias marcadoras ( $\mathrm{Rf} \sim 0,40$ e 0,46 ). Em destaque em Maytenus ilicifolia: mancha violeta: friedelanol; mancha amarela: friedelina.

\section{Material e Métodos}

Amostras de folhas Maytenus ilicifolia, Zollernia ilicifolia e Sorocea bonplandii foram coletadas em dezembro/ 99, março, abril, maio, junho, julho, agosto e setembro de $2000 \mathrm{e}$ devidamente identificadas por um dos autores (D.B.F.). As folhas foram submetidas à secagem sob temperatura ambiente e moídas em moinho de facas. Após, foram extraídas por maceração durante oito dias em diclorometano, na proporção drogasolvente 1:20. Os macerados foram concentrados em evaporador rotatório a vácuo em temperatura inferior a $40{ }^{\circ} \mathrm{C}$. Estes extratos foram analisados por $\mathrm{CCD}$ em vários sistemas cromatográficos, utilizando timol-sulfúrico ${ }^{9}$ e anisaldeído-sulfúrico ${ }^{10}$ como reveladores.

\section{Referências}

${ }^{1}$ Simões, C.M.O.; Mentz, L.A.; Schenkel, E.P.; Irgang, B.E.; Stehmann, J.R. Plantas da medicina popular do Rio Grande do Sul. Porto Alegre: Editora da Universidade UFRGS, 1995

${ }^{2}$ Carlini, E.A. \& Braz, S. Efeito protetor do liofilizado obtido no abafado de Maytenus sp (Espinheira-santa) contra úlcera gástrica experimental em ratos. In: Carlini, E.A. (Org.). Estudo de ação antiúlcera gástrica de plantas brasileiras (Maytenus ilicifolia "espinheira-santa" e outras). Brasília: Ministério da Saúde/CEME, 1988

${ }^{3}$ Geocze, S.; Vilela, M.P.; Chaves, B.D.R.; Ferrari, A.P. Tratamento de pacientes portadores de dispepsia alta ou de úlcera péptica com preparações de espinheira-santa (Maytenus ilicifolia). In: Carlini, E.A. (org.) Estudo de ação antiúlcera gástrica de plantas brasileiras (Maytenus ilicifolia "espinheira-santa" e outras). Brasília: Ministério da Saúde/CEME, 1998

${ }^{4}$ Nakamura, M.; Nakasumi, T.; Minagwa, Y.; Yoshizawa, T. CA 125: 123692j. Jpn. Kokai Tokkyo Koho JP 08,133,981 [96,133,981] (Cl. A61K35/78), 28 May 1996, Appl. 94/295,546, 4 Nov 1997

${ }^{5}$ Pagliarini, W.F.M. Levantamento das plantas de uso medicinal no Distrito de Ribeirão da Ilha. Florianópolis: Curso de Bacharelado em Ciências Biológicas da UFSC, 1995. Trabalho de Conclusão de Curso

${ }^{6}$ Freire, R.M. Levantamento das plantas de uso medicinal nas comunidades do Canto dos Araçás e Costa da Lagoa, Ilha de Santa Catarina, Florianópolis, SC. Florianópolis: Curso de Bacharelado em Ciências Biológicas da UFSC, 1996. Trabalho de Conclusão de Curso

${ }^{7}$ Vilegas, J.H.Y. ; Lanças, F.M. Detecção de adulterações em amostras comerciais de ' espinheira santa ' por cromatografia gasosa de alta resolução (HRCG). Revista de Ciências Farmacêuticas, 18 (2) : 241-248, 1997 
${ }^{8}$ Farias, M.R. Avaliação da qualidade de matérias-primas vegetais. In: Simões, C.M.O. et al. (Org.). Farmacognosia, da planta ao medicamento. Florianópolis/ Porto Alegre: Editora da UFSC/Editora da Universidade, 1999

${ }^{9}$ Merck, E. Dyeing reagent for thin layer and paper chromatography. Darmastadt: E. Merck, 1971

${ }^{10}$ Wagner, H.; BLADT, S. Plant drug analysis. 2ed. Berlin: Springer, 1995
Análise cromatográfica de fitoterápicos a base de espinheira-santa (Maytenus ilicifolia)

\author{
Michele Debiasi Alberton'; Daniel de Barcellos Falkenberg'; \\ Miriam de Barcellos Falkenberg ${ }^{3 *}$ \\ ${ }^{1}$ Programa de Pós Graduação em Farmácia \\ ${ }^{2}$ Departamento de Botânica \\ ${ }^{3}$ Departamento de Ciências Farmacêuticas \\ Centro de Ciências da Saúde, Universidade Federal de Santa \\ Catarina, Campus Universitário Trindade, 88040-900, \\ Florianópolis, SC, Brasil \\ miriam@ccs.ufsc.br.
}

\section{Resumo}

$\mathrm{Na}$ análise por CCD de fitoterápicos à base de espinheira-santa (Maytenus ilicifolia Martius ex Reissek (Celastraceae), dentre oito amostras analisadas, em apenas três delas foi identificada a presença de M.ilicifolia. Nas cinco amostras restantes, foram identificadas a presença de Zollernia ilicifolia e Sorocea bonplandii, duas espécies adulterantes. Em apenas uma das oito amostras foi constatada a ausência dos adulterantes citados.

Maytenus ilicifolia Martius ex Reissek (Celastraceae), conhecida popularmente como espinheira-santa, tem ação comprovada sobre úlceras gástricas e dispepsias em humanos ${ }^{1}$. É uma espécie comum no Sul e Sudeste do Brasil ${ }^{2}$, sendo bastante difundida na rede pública de saúde como alternativa de baixo custo para a população carente e sem recursos.

As folhas de Zollernia ilicifolia (Brongniart) Vogel (Fabaceae) e Sorocea bonplandii (Baillon) Burger, Lanjouw \& W. Boer (Moraceae) apresentam as margens espinhosas, sendo facilmente confundidas com a espinheira-santa ${ }^{3,4}$. Trabalhos visando o controle de qualidade de amostras comerciais de Maytenus ilicifolia tem sido desenvolvidos, utilizando, por exemplo, cromatografia gasosa detectando a presença de Sorocea bonplandii como adulterante 5 . Porém, até pouco tempo atrás, não havia marcadores químicos para serem utilizados em cromatografia em camada delgada para estas duas espécies. Recentemente identificamos três marcadores cromatográficos para Sorocea bonplandii e um para Zollernia ilicifolia ${ }^{6}$.

Por seu uso ser bastante difundido na medicina popular, atualmente existem no mercado inúmeras de preparações à base de Maytenus ilicifolia. Este trabalho teve por objetivo analisar oito marcas de fitoterápicos à base de espinheira-santa, com vistas a detectar a presença de adulterantes de espinheira-santa nestas amostras. A presença de Maytenus é confirmada nas 